\title{
Capital Market Development and Foreign Portfolio Investment Inflow in Nigeria (1985-2016)
}

\author{
Akinmulegun Sunday O. \\ Department of Banking and Finance, Adekunle Ajasin University, Nigeria
}

Copyright $\bigcirc 2018$ by authors, all rights reserved. Authors agree that this article remains permanently open access under the terms of the Creative Commons Attribution License 4.0 International License

\begin{abstract}
Investment as a catalyst for economic growth and development is an important prerequisite for an economy to attain and sustain industrialization. However, most developing countries lack the sufficient domestic capital to achieve the required level of investment necessary for growth. Thus, foreign capital is necessary to facilitate the investment-growth process. To attract adequate foreign capital needed for investment, capital market has been identified as one of the veritable means through which foreign investment flows into an economy. Consequently, this study examined the effect of capital market development on foreign portfolio investment in Nigeria over the period 1985 to 2016 . The study employed secondary data sourced from Central Bank of Nigeria Statistical Bulletin and publications of Nigeria Stock Exchange. In order to achieve the objective of the study, the researcher adopted Vector Error Correction Mechanism (VECM) to analyze the short run and long run dynamism of the variables while also focusing on the direction of causality between capital market development and foreign portfolio investment in Nigeria, using granger causality test. The Granger causality test revealed that there is no causality between capital market development and foreign portfolio investment in Nigeria. Result from the vector error correction model indicated that Market Capitalization (MCAP) has negative significant effect on foreign portfolio investment in Nigeria while All Share Index (ASI) has positive relationship with foreign portfolio investment. Therefore, the study concluded that capital market development has significant effect on foreign portfolio investment in Nigeria within the period examined. Based on the findings, the study recommended that government and capital market regulatory authorities should develop and enforce policies that will further propel capital market development in such a way that it will sustain its positive effect in attracting foreign portfolio into the Nigerian economy as well as stimulate improved interest of foreign investors in subscribing to portfolio investment in Nigerian enterprises.
\end{abstract}

Keywords Foreign Investment, Capital Market, Error
Correction, Share Index, Portfolio Theory

\section{Introduction}

One of the major challenges facing most developing economies is inadequate domestic investment that could ensure the achievement of desired economic growth. This is because there is an imbalance between the required capital and the available saving capability. To compensate for the insufficient savings, many developing countries at times resorted to foreign borrowing while some try as much as possible to attract foreign investment into their economy.

Foreign investment could be in form of direct investment or portfolio investment. Foreign direct investment is the commitment of investible funds by the national of a country into either a new company or an existing one, in a country other than his own, with the aim of exercising control over such company (Akinmulegun, 2011 [1]). Foreign portfolio investment on the other hand, involves owning financial assets or securities of companies by alien investors in a country other than their own country. Depending on the development and volatility of the capital market of recipient economy, portfolio investment offers liquidity to foreign investors. Foreign portfolio investment comes with huge capital into the recipient country through the financial market. These funds are usually intermediated through the financial market to facilitate domestic investment in the host country. Capital market has therefore been identified as one of the key factor that influences the inflow of portfolio investment into an economy towards economic growth.

However, the level of development of the host country's capital market will go a long way in determining the influx of portfolio investment into such a country. In the past few decades, foreign portfolio investment was not popular in Nigeria as evident by the available data which revealed that Nigeria has no record of portfolio investment, both inflow 
and outflow in her balance of payments account up to mid-1980s (Ozurumba, 2012 [2]). This majorly was due to the non-internationalization of Nigeria's money and capital markets. It has thus been pointed out that the role played by capital market as an effective means of attracting foreign investment is yet to be fully felt by the Nigeria economy. The domestication of the markets allowed for non-availability of relevant information on portfolio investments in foreign money and capital markets which do not encourage foreign investors. Ozurumba (2012), however noted that the liberalization of the Nigeria financial markets in mid-2000 resulted in the internationalization of the Nigeria Stock Exchange (NSE), and has led to an increase inflow of foreign investment into the nation through the capital market.

Diverse attempts have been made in the literature to examine the relationship between foreign investment (with focus on foreign direct investment) and economic growth as well as the effect of foreign direct investment on stock market development. \{Adaramola and Obisesan [3] (2015); Sulaiman and Mohammed [4] (2014); Tokunbo and Lloyd [5] (2010); Edu, Inaya and Bassey [6] (2015); Ajayi, Adejayan and Obalade [7] (2017); Akinmulegun [8] (2012); Okafor, Egiyi and Eyisi [9] (2017); Okpoto, S.I. [10] (2015)\}. It is worth noting however that the place of capital market development in attracting foreign portfolio investment into the nation's economy has been neglected by researchers in recent time. With this, the need for empirical investigation to fill the gap cannot be overemphasized. Thus, this study intends to examine the effect of capital market development on foreign portfolio investment in Nigeria. In the light of this, the study attempts to answer the following questions: What is the effect of market capitalization on foreign portfolio investment in Nigeria? What is the effect of All Share Index on foreign portfolio investment in Nigeria?

\section{Literature Review}

\section{Theoretical Review}

This study attempts the discussion of the following investment theories:

\section{Marginal Efficiency Hypothesis}

This hypothesis considers investors investment decisions as a function of internal rate of return (IRR) generated by investing in a particular asset called Marginal Efficient of Investment (MEI) and the prevailing market rate of interest rate. This theory, propounded by John Maynard Keynes in his general theory defined internal rate of return (IRR) as "the rate of discount which would make the present value of the series of annuities given by the returns expected from the capital asset during its life just equal its supply price". In his attempt to further explain this theory, Keynes utilized the concept of marginal efficiency of capital (MEC). He defined marginal efficiency of capital as the rate of discount which would equate the price of a fixed capital asset with its present discounted value of expected income. According to him, the MEC is the net rate of return that is expected from the purchase of additional capital. It is calculated as the profit that a firm is expected to earn considering the cost of inputs and the depreciation of capital. It is influenced by expectations about future input costs and demand. According to this hypothesis, for investment to take place the following conditions must be satisfied: MEC $>r$, accept investment proposal; MEC $<\mathrm{r}$, reject investment proposal. The rule further defined, $r$, as the market rate of interest and states that where $\mathrm{MEC}=r$, investment is considered to be at its optimum or equilibrium level.

\section{The Modern Portfolio Theory}

Modern Portfolio Theory (MPT) was put forward by Harry Markowitz in his paper "Portfolio Selection" published in 1952. The theory emphasized that risk is an inherent part of higher reward. MPT is one of the most important and influential financial theories that deals with finance and investment.

Modern portfolio theory (MPT) is a mathematical framework for assembling a portfolio of assets such that the expected return is maximized for a given level of risk, defined as variance. Its key insight is that an asset's risk and return should not be assess by itself, but by how much it contribute to portfolio's overall risk and return. MPT assumes that investors are risk averse. This means that given two portfolios that offer equal expected return, investors will prefer the less risky one. Thus, an investor will take on increased risk only if compensated by higher expected returns. Conversely, an investor who wants higher expected return must assume more risk. This theory submits that the exact trade-off will be the same for investors, but different investors will evaluate the trade-off differently based on individual risk behaviour. MPT explained that by investing in more than one asset, an investor can reap the benefits of diversification, particularly a reduction in the riskiness of the portfolio, (not putting all of ones eggs in one basket). Markowitz showed that investment is not just about picking assets, but about choosing the right combination of assets among which to spread one's risk.

In general, Markowitz formula is given thus:

$$
\text { Expected return of portfolio: } \mathrm{E}\left(\mathrm{R}_{p}\right)=\sum \mathrm{w}_{i} \mathrm{E}\left(\mathrm{R}_{i}\right)
$$

Where: $\mathrm{Rp}=$ return on portfolio

$\mathrm{Ri}=$ return on asset $i$

$\mathrm{Wi}=$ weight of component asset $i$ in the portfolio

\section{Empirical Review}

The fact that several studies have been conducted on 
foreign investment and capital market in Nigeria cannot be overemphasized. Adaramola and Obisesan [3] (2015) examined the impact of foreign direct investment on capital market development in Nigeria from 1970 to 2010. Adopting Augmented Dickey Fuller unit root test and co-integration to analyze the secondary data obtained from Central Bank of Nigeria, the study revealed that there is no co-integration between foreign direct investment and capital market. Using Ordinary Least Square (OLS) estimation technique, the result established that foreign direct investment has positive and significant impact on capital market within the period of study. The study submitted that, since foreign direct investment is a significant determinant of capital market development in Nigeria, efforts should be made by government to encourage the flow of foreign direct investment into the country. In a related study, Odo, Anoke, Nwachukwu and Promise [11] (2016) investigated the impact of foreign direct investment on stock market growth in Nigeria. Using times series data from 1984 to 2015 , the study revealed that there is no causality between foreign direct investment and stock market growth in Nigeria. Their findings also showed that foreign direct investment (FDI) and export have negative relationship with stock market growth both in the long and short run periods, thus, concluded that foreign direct investment has no significant impact on stock market growth within the period of study. Consequently, the study recommended that government should put policy measure in place that would ensure active participation of foreign investors sourcing for investment funds in the Nigeria stock market.

The study of Onyeisi, Odo and Anoke [12] (2016) empirically examined the impact of foreign portfolio investment inflows on stock market growth in Nigeria from 1986 to 2014. The study employed co-integration, vector error correction mechanism and Granger causality econometric analytical methods. They found that there is co-integration between foreign portfolio investment and stock market growth and that foreign portfolio investment has significant long-run impact on stock market growth in Nigeria within the period of the study. However, the result of the study showed that there is no causality between foreign portfolio investment and stock market in Nigeria. They thus recommended that federal government should strengthen the Security and Exchange Commission (SEC) so as to stimulate constant inflow of foreign portfolio investment to Nigeria economy.

In his quest to contribute to the stock of existing literature, Eniekezimene [13] (2013) empirically examined the impact of foreign portfolio investment on capital market growth in Nigeria. In an attempt to achieve its objective, the study x-rays the growth of FPI in the market as well as the transmission channels through which the changes in foreign portfolio investment affect growth of the capital market. Adopting ordinary least square (OLS) method and parsimonious error correction model, the study reported that foreign portfolio investment has a positive impact on capital market growth in Nigeria.

Ekeocha, Ekeocha, Malaolu and Oduh [14] (2012) studied the determinants of foreign portfolio investment in Nigeria over the period, 1981 to 2010 . While modeling the long-run determinants of foreign portfolio investment (FPI), they included variables of market capitalization, real interest rate, trade openness, real exchange rate and real gross domestic product to actually establish the extent to which each of the included variables influence the inflow of foreign portfolio investment into Nigeria. Using time series data, the study employed finite distributed lag model and the result showed that foreign portfolio investment has positive relationship with market capitalization and trade openness in Nigeria. Ekeocha et al. [14] (2012) in this study recommended that government should not relent in its efforts to sanitize the capital market. Similarly, Baghebo and Apere [15] (2014) attempted to assess the impact of foreign portfolio investment (FPI) on economic growth in Nigeria between 1986 and 2011. The study adopted three stage methodological processes to ensure proper estimation of the included variables. Form the findings of the study, it was discovered that foreign portfolio investment, market capitalization and trade openness have positive long-run relationship with real gross domestic product in Nigeria within the period of study.

Sulaiman and Mohammed [4] (2014), employed Johansen co-integration and error correction technique to investigate the impact of foreign direct investment and macroeconomic stability on stock market development in Nigeria between 1981 and 2010. The result showed that there is long-run relationship among the variables included in the study; also that foreign direct investment has positive but insignificant impact on stock market development in Nigeria within the period of the study. The study recommended that foreign firms in the Nigeria's oil and gas and telecommunication sectors should be encouraged to be listed on the capital market so as to promote the development of the market.

Similar studies that existed in the literature include, Ajayi, Adejayan and Obalade [7] (2017), Abel, Ebele and Ndi [16] (2009), Okpoto [10] (2015), Ozurumba [2] (2012). One common feature of the studies and the other discussed above is fundamentally on their policy recommendation. While in most cases, their recommendations are government policies oriented, the impact of environment was missing. As good as government policy orientation may look like, the place of conducive business environment cannot be over emphasised.

With the view to establishing empirical relationship between foreign portfolio investment and industrial productivity in Nigeria, Osmond [17] (2016) examined the effect of foreign portfolio investment on industrial growth in Nigeria from 1986 to 2013. Sourcing secondary data from the Central bank of Nigeria, the study employed Ordinary Least Square (OLS) estimation technique to 
establish the relationship among the included variables. The findings of the study revealed that there is statistically significant positive relationship among foreign portfolio investment, gross fixed capital formation, market capitalization and industrial growth in Nigeria. The study therefore recommended that market capitalization should be expanded in order to stimulate industrial productivity in Nigeria.

Muhammad, Muhammad, Shamila and Shujahat [18](2017) examined the impact of stock market performance on foreign portfolio investment in China. Using quarterly time series data from 2007 to 2015, the study adopted auto regressive distributed lag model. The results of the study showed that stock market performance has significant positive impact on foreign portfolio investment, whereas inflation was negatively associated with foreign portfolio investment. The study further revealed that historical events, such as Asian financial crisis of 2008 and the Shanghai composite Stock Index of 2015 , significantly affected foreign portfolio investment in China.

In the attempt to ascertain what effect foreign direct investment has on stock market in Pakistan, Irfan [19] (2014) conducted an empirical research to investigate the impact of Foreign Direct Investment (FDI) on volatility of Pakistan Stock Market. The variables used in the study include market capitalization, FDI, Gross National Product (GNP) and inflation. Employing regression method of analysis, the result revealed that foreign direct investment has positive impact on the development of stock market in Pakistan. Related studies include that of Ali, Nasir, Zeshan, Mohammad and Tanvir [20] (2012) on Pakistan, and Sameh [21] (2017) on Jordan.

From the reviewed literature, it is evident that there is no consensus as to the relationship between foreign portfolio investment (FPI) and capital market development in Nigeria. While the literature is flooded with the impact of foreign portfolio investment either on stock market growth or on economic growth, little attention has been given by scholars to the study of the impact of capital market development on foreign portfolio attraction into Nigeria economy. Therefore, this study set out to fill this gap by investigating the impact of capital market development on foreign portfolio investment inflow in Nigeria.

\section{Methodology}

To estimate the effect of the explanatory variables on the dependent variable, the study adopted vector error correction model. This is because it helps to adjust the short run disequilibrium among the variables and also establish the behavioral reaction of the variables relative to each other. Granger causality test was also adopted to establish the direction of causality among the relevant variables.

To avert the problem of spurious regression result, the researcher conducted the unit root test to determine the stationarity or otherwise of the time series data, using Augmented Dickey Fuller (ADF) unit root test..

The data used for this study were secondary data sourced from the Central Bank of Nigeria Statistical Bulletin and publications of Nigeria Stock Exchange, various issues. The aggregate data used for the study were annual time series data which covered the period of 1985 to 2016 .

\section{Model Specification}

The model for this study is anchored on the modern portfolio theory developed by Harry Markowitz. It is an investment hypothesis centered on the idea that risk-averse investors can construct portfolios to optimize expected return based on a given level of market risk. Thus, the response of foreign investors in constructing a portfolio of various assets depends on the development of the capital market to guide against the vulnerability of investors' funds. The model construct for this study is therefore fashioned according to the work of Ekeocha, et al. [14] (2012) and Muhammad, et al. [18] (2017) as modified below;

$$
\mathrm{FPI}=\mathrm{F}(\mathrm{MCAP}, \mathrm{ASI}, \mathrm{RGDP}, \mathrm{EXCHR}, \mathrm{INTR})
$$

Explicitly, equation 1 is given as:

$$
\begin{aligned}
\text { FPI }_{t}= & \alpha_{0}+\alpha_{1} \text { MCAP }_{t}+\alpha_{2} \text { ASI }_{t}+\alpha_{3} \text { RGDP }_{t}+ \\
& +\alpha_{4} \text { EXCHR }_{t}+\alpha_{5} \text { INTR }_{t}+\mu_{t}
\end{aligned}
$$

From equation 2 , the $\log$ of the variables is given as:

$$
\begin{gathered}
\operatorname{logFPI} \mathrm{t}_{\mathrm{t}}=\alpha_{0}+\alpha_{1} \log \mathrm{MCAP}_{\mathrm{t}}+\alpha_{2} \log \mathrm{ASI}_{\mathrm{t}}+ \\
+\alpha_{3} \operatorname{logRGDP} \mathrm{f}_{\mathrm{t}}+\alpha_{4} \log \mathrm{EXCHR}_{\mathrm{t}}+\alpha_{5} \log \mathrm{INTR}_{\mathrm{t}}+\mu_{\mathrm{t}}
\end{gathered}
$$

Where:

FPI $=$ Foreign Portfolio Investment

$\mathrm{MCAP}=$ Market capitalization (proxy for capital market development)

$\mathrm{ASI}=$ All share index

RGDP $=$ Real Gross domestic Product

$\mathrm{EXCHR}=$ Exchange rate

$\mathrm{INTR}=$ Interest Rate

$\alpha_{1}-\alpha_{5}=$ Coefficients of explanatory variables.

$\mu=$ error term.

Theoretically, it is expected that $\alpha_{1}, \alpha_{2}, \alpha_{3}, \alpha_{4}>0$ while $0<\alpha_{5}<0$. That is MCAP, ASI, RGDP and EXCHR should be positively related to FPI while INTR could either be positive or negative depending on the state of the economy and interest rate changes. 


\section{Presentation and Interpretation of Results}

\section{Descriptive Statistics}

Table 1. Descriptive statistics

\begin{tabular}{|c|c|c|c|c|c|}
\hline & LOGMCAP & LOGFPI & LOGRGDP & EXCHR & INTR \\
\hline Mean & 27.01094 & 21.99942 & 31.02380 & 89.16370 & 18.53794 \\
\hline Median & 27.05008 & 22.02866 & 30.82827 & 109.8486 & 17.96500 \\
\hline Maximum & 30.57953 & 25.25068 & 31.86547 & 305.2237 & 29.80000 \\
\hline Minimum & 22.61034 & 18.83676 & 30.33599 & 0.959500 & 9.250000 \\
\hline Std. Dev. & 2.790930 & 1.641507 & 0.513522 & 76.01649 & 4.129980 \\
\hline Skewness & -0.200981 & -0.019758 & 0.348249 & 0.559605 & 0.508838 \\
\hline Kurtosis & 1.628110 & 2.230520 & 1.670367 & 2.949509 & 4.269757 \\
\hline Jarque-Bera & 2.724876 & 0.766812 & 3.004046 & 1.673573 & 3.530599 \\
\hline Probability & 0.256036 & 0.681536 & 0.222679 & 0.433100 & 0.171136 \\
\hline Sum & 864.3500 & 681.9821 & 992.7616 & 2853.238 & 593.2140 \\
\hline Sum Sq. Dev. & 241.4680 & 80.83639 & 8.174845 & 179133.7 & 528.7587 \\
\hline Observations & 32 & 31 & 32 & 32 & 32 \\
\hline
\end{tabular}

Source: Author's computation, 2018.

Table 2. Unit root result

\begin{tabular}{|c|c|c|c|c|c|c|}
\hline \multirow[t]{2}{*}{ Variables } & \multicolumn{3}{|c|}{ ADF statistics } & \multicolumn{2}{|c|}{ Critical values } & \multirow[t]{2}{*}{ Order of integration } \\
\hline & At level & $1^{\text {st }}$ diff & $2^{\text {nd }}$ diff & $5 \%$ & $10 \%$ & \\
\hline LOGFPI & -3.560801 & - & - & -2.967767 & -2.622989 & $1(0)$ \\
\hline LOGMCAP & -1.190307 & -4.173387 & - & -2.963972 & -2.621007 & $1(1)$ \\
\hline LOGASI & -2.577758 & -3.881875 & - & -2.967767 & -2.622989 & $1(1)$ \\
\hline LOGRGDP & -0.330429 & -2.795609 & - & -2.963972 & -2.621007 & $1(1)$ \\
\hline EXCHR & 1.395336 & -2.182186 & -5.858556 & -2.967767 & -2.622989 & $1(2)$ \\
\hline INTR & -4.125086 & - & - & -2.960411 & -2.619160 & $1(0)$ \\
\hline
\end{tabular}

Source: Author's computation, 2018.

The descriptive statistics of the variables are shown as presented in table 1 above. As revealed by the result, all the variables exhibit positive mean. The standard deviations of the variables show the dispersion of the variables from their mean. The result shows that the variables (like FPI, MCAP, ASI, RGDP and INTR) have low standard deviations indicating that the variables do not deviate widely from their mean values with the exception of EXCHR with a higher value (76.01649). This is as shown by their respective standard deviation values. The Jarque-Bera statistic is estimated to test the normality of the variables. The Jarque-Bera estimates as shown above indicate that the variables are normality distributed at $5 \%$ level of significance. This is as indicated by their respective skewness and kurtosis.

\section{Stationarity Test}

The condition for the stationarity of the variables is that the ADF statistic must be greater than the critical values in their absolute term. Consequently, from table 2, foreign portfolio investment (FPI) and interest rate (INTR) are free from the problem of unit root. They are integrated of order zero $1(0)$ as revealed by their result. On the other hand, MCAP, ASI, and RGDP are all integrated of order one 1(1). That is after purging them of unit root problem by differencing them; they became stationary at first difference as indicated by their result in table 2 . However, 
exchange rate (EXCHR) was integrated of order two 1(2). That is, it became stationary at second difference.

\section{Causality Test}

Table 3. Granger causality result

\begin{tabular}{|c|c|c|c|}
\hline Null Hypothesis: & Obs & F-Statistic & Prob. \\
\hline $\begin{array}{c}\text { LOGMCAP does not Granger } \\
\text { Cause LOGFPI }\end{array}$ & 28 & 0.99356 & 0.4151 \\
\hline \multicolumn{2}{|c|}{ LOGFPI does not Granger Cause LOGMCAP } & 0.46841 & 0.7075 \\
\hline $\begin{array}{c}\text { LOGASI does not Granger } \\
\text { Cause LOGFPI }\end{array}$ & 28 & 0.65362 & 0.5896 \\
\hline LOGFPI does not Granger Cause LOGASI & 0.86519 & 0.4746 \\
\hline $\begin{array}{c}\text { LOGRGDP does not Granger } \\
\text { Cause LOGFPI }\end{array}$ & 28 & 3.72445 & 0.0272 \\
\hline LOGFPI does not Granger Cause LOGRGDP & 1.91767 & 0.1577 \\
\hline
\end{tabular}

Source: Author's computation, 2018.

The Granger causality result is presented in table 3 . The result revealed that there is no causality between the proxies of capital market (MCAP and ASI) and foreign portfolio investment in Nigeria within the period under study. This implies that capital market development does not induce the attraction of foreign portfolio investment into Nigerian economy within the period covered in this study. This result is in line with the study of Onyeisi, Odo and Anoke [12] (2016) which submitted that there is no causality between foreign portfolio investment and stock market growth in Nigeria. However, this result indicates that there is unidirectional causality between foreign portfolio investment and economic growth in Nigeria. The causality runs from economic growth to foreign portfolio investment. The implication of this is that economic growth induced the inflow of foreign portfolio investment into the economy considering the period under study.

\section{Vector Error Correction Mechanism (VECM)}

Table 4. Result from VECM

\begin{tabular}{|c|c|c|c|c|c|c|}
\hline Error Correction: & D(LOGFPI) & D(LOGMCAP) & D(LOGASI) & D(LOGRGDP) & $\mathrm{D}(\mathrm{EXCHR})$ & $\mathrm{D}(\mathrm{INTR})$ \\
\hline \multirow[t]{3}{*}{ CointEq1 } & -1.691395 & 0.188837 & 0.208150 & -0.004226 & -3.782874 & 0.000433 \\
\hline & $(0.51331)$ & $(0.13266)$ & $(0.12816)$ & $(0.01414)$ & (7.10633) & $(1.86767)$ \\
\hline & {$[-3.29510]$} & {$[1.42346]$} & {$[1.62414]$} & {$[-0.29887]$} & {$[-0.53232]$} & {$[0.00023]$} \\
\hline \multirow[t]{3}{*}{ D(LOGFPI(-1)) } & 0.725245 & -0.077075 & -0.088593 & -0.000770 & 4.283460 & 0.652969 \\
\hline & $(0.31131)$ & $(0.08046)$ & $(0.07773)$ & $(0.00858)$ & $(4.30984)$ & $(1.13270)$ \\
\hline & [ 2.32966] & {$[-0.95798]$} & {$[-1.13981]$} & {$[-0.08984]$} & [ 0.99388] & {$[0.57647]$} \\
\hline \multirow[t]{3}{*}{ D(LOGFPI(-2)) } & -0.169284 & -0.084265 & -0.102400 & 0.002401 & -0.787463 & 0.082839 \\
\hline & $(0.21019)$ & $(0.05432)$ & $(0.05248)$ & $(0.00579)$ & $(2.90998)$ & $(0.76479)$ \\
\hline & {$[-0.80537]$} & {$[-1.55118]$} & {$[-1.95120]$} & {$[0.41468]$} & {$[-0.27061]$} & {$[0.10832]$} \\
\hline \multirow[t]{3}{*}{ D(LOGMCAP(-1)) } & -7.362178 & 0.877127 & 0.338402 & -0.003867 & -6.362690 & -2.591093 \\
\hline & $(3.50698)$ & $(0.90635)$ & $(0.87561)$ & $(0.09660)$ & $(48.5514)$ & $(12.7602)$ \\
\hline & {$[-2.09929]$} & {$[0.96776]$} & {$[0.38648]$} & {$[-0.04003]$} & {$[-0.13105]$} & {$[-0.20306]$} \\
\hline \multirow[t]{3}{*}{ D(LOGMCAP(-2)) } & -9.103817 & 0.617365 & 1.032229 & 0.055744 & -56.31428 & -6.223977 \\
\hline & $(3.39415)$ & $(0.87719)$ & $(0.84744)$ & $(0.09349)$ & $(46.9895)$ & $(12.3496)$ \\
\hline & {$[-2.68221]$} & {$[0.70380]$} & [ 1.21806$]$ & {$[0.59623]$} & {$[-1.19844]$} & {$[-0.50398]$} \\
\hline \multirow[t]{3}{*}{ D(LOGASI(-1)) } & 7.463608 & -0.450659 & -0.005136 & 0.022087 & -17.63941 & -3.237296 \\
\hline & $(3.86457)$ & $(0.99877)$ & $(0.96489)$ & $(0.10645)$ & $(53.5020)$ & $(14.0612)$ \\
\hline & [ 1.93129$]$ & {$[-0.45122]$} & {$[-0.00532]$} & {$[0.20748]$} & {$[-0.32970]$} & {$[-0.23023]$} \\
\hline \multirow[t]{3}{*}{ D(LOGASI(-2)) } & 8.999248 & -1.057753 & -1.329478 & -0.039678 & 58.11318 & 4.027403 \\
\hline & $(3.62039)$ & $(0.93566)$ & $(0.90392)$ & $(0.09973)$ & $(50.1215)$ & (13.1728) \\
\hline & {$[2.48571]$} & {$[-1.13049]$} & {$[-1.47079]$} & {$[-0.39787]$} & [ 1.15945$]$ & {$[0.30574]$} \\
\hline \multirow[t]{3}{*}{ D(LOGRGDP(-1)) } & 24.45842 & -0.109353 & -2.735785 & 0.111283 & 81.24591 & -10.20315 \\
\hline & $(13.3478)$ & $(3.44963)$ & $(3.33261)$ & $(0.36767)$ & (184.790) & $(48.5659)$ \\
\hline & [ 1.83240$]$ & {$[-0.03170]$} & {$[-0.82091]$} & [ 0.30267$]$ & [ 0.43967$]$ & [-0.21009] \\
\hline D(LOGRGDP(-2)) & -26.12679 & -0.734460 & -0.073200 & 0.440985 & -131.4926 & -7.799295 \\
\hline
\end{tabular}




\begin{tabular}{|c|c|c|c|c|c|c|}
\hline & (10.7499) & $(2.77823)$ & (2.68399) & $(0.29611)$ & (148.824) & $(39.1136)$ \\
\hline & {$[-2.43042]$} & {$[-0.26436]$} & {$[-0.02727]$} & [ 1.48925$]$ & {$[-0.88354]$} & {$[-0.19940]$} \\
\hline \multirow[t]{3}{*}{ D(EXCHR(-1)) } & 0.024247 & 0.003372 & 0.002307 & 0.000511 & -0.175745 & -0.108444 \\
\hline & $(0.02513)$ & $(0.00650)$ & $(0.00628)$ & $(0.00069)$ & $(0.34797)$ & $(0.09145)$ \\
\hline & [ 0.96468$]$ & {$[0.51906]$} & {$[0.36760]$} & {$[0.73816]$} & {$[-0.50506]$} & {$[-1.18580]$} \\
\hline \multirow[t]{3}{*}{$\mathrm{D}(\operatorname{EXCHR}(-2))$} & 0.000941 & -0.001647 & 0.000382 & 0.000465 & 0.185332 & -0.017756 \\
\hline & $(0.02485)$ & $(0.00642)$ & $(0.00620)$ & $(0.00068)$ & $(0.34400)$ & $(0.09041)$ \\
\hline & {$[0.03788]$} & {$[-0.25654]$} & {$[0.06151]$} & [ 0.67992] & [ 0.53876$]$ & {$[-0.19640]$} \\
\hline \multirow[t]{3}{*}{ D(INTR(-1)) } & -0.158048 & 0.015095 & 0.034062 & 0.002781 & 0.010791 & -0.512457 \\
\hline & $(0.11073)$ & $(0.02862)$ & $(0.02765)$ & $(0.00305)$ & (1.53303) & $(0.40291)$ \\
\hline & {$[-1.42727]$} & {$[0.52745]$} & [ 1.23200$]$ & [ 0.91171] & [ 0.00704$]$ & {$[-1.27190]$} \\
\hline \multirow[t]{3}{*}{$\mathrm{D}(\operatorname{INTR}(-2))$} & -0.155881 & -0.013921 & 0.008394 & 0.000450 & -1.018750 & -0.069080 \\
\hline & $(0.09708)$ & $(0.02509)$ & $(0.02424)$ & $(0.00267)$ & (1.34397) & $(0.35322)$ \\
\hline & {$[-1.60573]$} & {$[-0.55485]$} & {$[0.34632]$} & [ 0.16843$]$ & {$[-0.75801]$} & {$[-0.19557]$} \\
\hline \multirow[t]{3}{*}{$\mathrm{C}$} & 1.406791 & 0.205489 & 0.208106 & 0.007787 & 18.76901 & 4.040310 \\
\hline & $(0.71253)$ & $(0.18415)$ & $(0.17790)$ & $(0.01963)$ & $(9.86444)$ & $(2.59255)$ \\
\hline & [ 1.97436$]$ & [ 1.11589$]$ & [ 1.16978$]$ & [ 0.39676$]$ & [ 1.90269$]$ & [ 1.55843] \\
\hline R-squared & 0.748472 & 0.413342 & 0.493123 & 0.464824 & 0.359310 & 0.459890 \\
\hline Adj. R-squared & 0.514910 & -0.131413 & 0.022452 & -0.032126 & -0.235616 & -0.041641 \\
\hline Sum sq. resids & 22.18585 & 1.481845 & 1.383019 & 0.016834 & 4252.205 & 293.7122 \\
\hline S.E. equation & 1.258850 & 0.325340 & 0.314304 & 0.034676 & 17.42782 & 4.580332 \\
\hline F-statistic & 3.204596 & 0.758767 & 1.047703 & 0.935354 & 0.603957 & 0.916973 \\
\hline
\end{tabular}

Source: Author's computation, 2018.

From table 4, the Vector error correction equation is stated thus:

$$
\begin{aligned}
& \mathrm{D}(\text { LOGFPI })=-1.69139513597 *(\text { LOGFPI(-1) }- \\
& \text { 3.53846543144*LOGMCAP }(-1)+ \\
& 2.34179896636 * \text { LOGASI }(-1)+ \\
& 11.7409417305 * \text { LOGRGDP(-1) - } \\
& 0.0186936747151 * \operatorname{EXCHR}(-1) \text { - } \\
& 0.0322996493241 * \operatorname{INTR}(-1)-308.701286197)+ \\
& 0.725244753012 * \mathrm{D}(\text { LOGFPI(-1)) - } \\
& 0.169284053432 * \mathrm{D}(\text { LOGFPI(-2)) - } \\
& 7.3621775665 * \mathrm{D}(\operatorname{LOGMCAP}(-1))- \\
& \text { 9.10381715769*D(LOGMCAP(-2)) + } \\
& 7.46360812447 * \mathrm{D}(\text { LOGASI }(-1))+ \\
& 8.99924775324 * \mathrm{D}(\text { LOGASI }(-2))+ \\
& \text { 24.4584208071*D(LOGRGDP(-1)) - } \\
& 26.126786934 * \mathrm{D}(\text { LOGRGDP }(-2))+ \\
& 0.0242467391567 * \mathrm{D}(\operatorname{EXCHR}(-1))+ \\
& 0.000941212260165 * \mathrm{D}(\operatorname{EXCHR}(-2))- \\
& 0.158047952727 * \mathrm{D}(\mathrm{INTR}(-1))- \\
& 0.15588110985 * \mathrm{D}(\operatorname{INTR}(-2))+1.40679146111
\end{aligned}
$$

From the VECM result, the coefficient of error correction is -1.691395 . The coefficient of ECM is appropriately signed. The coefficient indicates that the short run disequilibrium will be corrected in the long run at the rate of $169 \%$. From the result, the coefficient of market capitalization (MCAP) is negative (-7.362178). This indicates that there is a direct negative relationship between market capitalization and foreign portfolio investment in Nigeria. The implication of this is that a unit increase in market capitalization (proxy of capital market development) would induce 7.36 unit decreases in the inflow of foreign portfolio investment into Nigeria economy. The result indicated that market capitalization (MCAP) exhibits a negative significant effect on foreign portfolio investment. This is as indicated by the t. statistics of -2.10 . This result negates the finding of Muhammad, Muhammad, Shamila and Shujahat [18] (2017) on China, which submitted that stock market performance has significant positive impact on Foreign Portfolio Investment. Also in terms of relationship, this result contradicts the findings of Ekeocha et al. [14] (2012) and Baghebo and Apere [15] (2014), which posited that foreign portfolio investment and market capitalization are positively related.

From table 4, All Share Index (ASI) exhibits a positive relationship with foreign portfolio investment as indicated by the coefficient of 7.46360 at lag one. This implies that increase in All Share Index on the capital market will result to a positive effect on foreign portfolio investment. Also, at lag two (-2) All Share Index (ASI) reveals a positive coefficient of 8.999248 and this implies that All Share 
Index has a positive effect on foreign portfolio investment both at lag one (-1) and lag two (-2). Statistically, All Share Index is significant at lag (-2). The significant effect of the capital market indicators (MCAP and ASI) corroborates the fact that capital market development is an important determinant for the inflow of foreign portfolio investment into Nigerian economy. This is in agreement with Abel, Ebele and Ndi [16] (2009), which submitted that growth in the Nigerian stock market has contributed to increased portfolio investment. In other words, capital market growth has induced increased inflow of foreign private investment of which portfolio investment is one.

Real gross domestic product, as one of the determinants of foreign portfolio investment as treated in this study, exhibits a positive relationship but insignificant effect on foreign portfolio investment. This is as indicated by the coefficient and $T$. statistic of 24.45842 and 1.83 respectively. The positive relationship of RGDP with foreign portfolio investment agrees with our a priori expectation. This implies that a unit increase in real gross domestic product will impact 24.45 units increase in foreign portfolio investment.

As expected, exchange rate has a positive effect on the inflow of foreign portfolio investment into the Nigeria economy at lag one (-1) and lag two (-2) as shown by the positive coefficient of 0.024247 and 0.000941 . But the effect is not significant at $5 \%$ level of significance as indicated by the T statistic of 0.96468 and 0.03788 at both lag ne and lag two respectively. The insignificant effect of exchange rate could be attributed to the persistent unfavorable fluctuation of Nigeria currency in the international market relative to other foreign currencies. In line with the a priori expectation interest rate has a negative relationship with foreign portfolio investment. This is as indicated by a negative coefficient of -0.158048 .

From the result, the goodness of fit is good as indicated by the coefficient of determination $\left(\mathrm{R}^{2}\right)$ which is $74.85 \%$. This indicates that approximately $75 \%$ of the total variations in foreign portfolio investment are explained by the explanatory variables, while the remaining $25 \%$ is explained by other variables not included in the model and these are captured by the error term.

\section{Variance Decomposition of FPI}

Variance decomposition measures the contribution of each variable to own shocks and to the shocks of other variables in the system as explained. The variance decomposition of foreign portfolio investment (FPI) is presented in this study. However, other variables included in this study can be explained in similar way as the interpretation given to foreign portfolio investment. Period 1 to 10 is considered in explaining the shock in FPI. In period one, foreign portfolio investment explained $100 \%$ of its own forecast variance. The percentage of variance that could be attributed to other variables in the second period are: MCAP account for about $0.04 \%$, ASI about $0.84 \%$, RGDP about $0.99 \%$, EXCHR about $4.32 \%$ and INTR about $0.59 \%$. Other periods can be explained along this same line of reasoning.

Table 5. Variance decomposition result (FPI)

\begin{tabular}{|c|c|c|c|c|c|c|c|}
\hline Period & S.E. & LOGFPI & LOGMCAP & LOGASI & LOGRGDP & EXCHR & INTR \\
\hline 1 & 1.258850 & 100.0000 & 0.000000 & 0.000000 & 0.000000 & 0.000000 & 0.000000 \\
\hline 2 & 1.436901 & 93.20464 & 0.040693 & 0.842929 & 0.993940 & 4.321218 & 0.596578 \\
\hline 3 & 1.786765 & 61.91599 & 1.093724 & 0.559592 & 25.63110 & 10.31446 & 0.485129 \\
\hline 4 & 2.265007 & 50.46508 & 1.422179 & 6.393051 & 34.22383 & 7.053295 & 0.442565 \\
\hline 5 & 2.670223 & 47.69075 & 1.412307 & 15.51129 & 26.52633 & 8.118795 & 0.740522 \\
\hline 6 & 2.917236 & 48.63071 & 2.862891 & 13.41991 & 27.13666 & 6.910168 & 1.039658 \\
\hline 7 & 3.096025 & 48.01442 & 2.725971 & 12.01010 & 29.59133 & 6.699138 & 0.959037 \\
\hline 8 & 3.285463 & 46.51452 & 2.420686 & 15.69263 & 28.46293 & 6.056378 & 0.852849 \\
\hline 9 & 3.553950 & 45.70829 & 2.175400 & 17.73263 & 26.94455 & 6.367953 & 1.071168 \\
\hline 10 & 3.718156 & 46.69984 & 2.254882 & 16.63044 & 27.52189 & 5.819638 & 1.073308 \\
\hline
\end{tabular}

Source: Author's computation, 2018. 


\section{Conclusions and Policy Recommendations}

This study examines the effect of capital market development on foreign portfolio investment in Nigeria. The findings revealed that capital market development indicator included in this study, market capitalization (MCAP), have negative significant effect on foreign portfolio investment in Nigeria. With All Share Index (ASI) exhibiting a positive relationship with foreign portfolio investment, therefore, the study concluded that capital market development have significant effect on foreign portfolio investment in Nigeria within the period considered.

Consequently, it is recommended that government and capital market regulatory authorities should develop and implement proper policies that will enhance better performance of the capital market as it affects the inflow of foreign portfolio investment into the Nigerian economy. Conclusively, the negative effect of capital market on foreign portfolio investment could be as a result of the developing nature of the Nigerian economy as a whole. Thus, it is recommended that future studies can consider other factors such as the financial depth and deepening of the Nigerian financial sector and political scenario existing in the country.

\section{REFERENCES}

[1] Akinmulegun, S. O. (2011). Globalization, Foreign Direct Investment and Economic Growth in Nigeria, (1986-2009), Ekiti State University, Ado-Ekiti; PhD Thesis.

[2] Ozurumba, B. A. (2012). The Impact of Stock Market Returns on Foreign Portfolio Investment in Nigeria. IOSR Journal of Business and Management. 2(4), 10-19.

[3] Adaramola, A. O. \& Obisesan, O. G. (2015).Impact of Foreign Direct Investment on Nigeria Capital Market Development. International Journal of Academic Research in Accounting, Finance and Management Science, 5(1), 103-108.

[4] Sulaiman, U. M. \& Mohammed, I. (2014). Stock Market Development, Foreign Direct Investment and Macroeconomic Stability: Evidence from Nigeria. Research Journal of Finance and Accounting, 5(18), 258-264.

[5] Tokunbo, S. O. (2010). Foreign Private Investment and Economic Growth in Nigeria. Applied Econometrics and International Development, 10(2), 189-204.

[6] Edu, G. T., Inaya, L. \& Bassey, A. F. (2015).Foreign Private Capital Inflows and Economic Growth in Nigeria. European Journal of Business and Social Sciences, 4(8), 205-217.

[7] Ajayi, L. B., Adejayan, A.O. \& Obalade, A. A. (2017).Impact of Foreign Private Investment on the
Development of Nigerian Capital Market. International Journal of Economics, Business and Management Research, 1(2), 120-132.

[8] Akinmulegun, S. O. (2012). The Dynamic Position of Foreign Direct Investment (FDI) in Economic Growth of a Nation: Nigeria Experience. Journal of the Social and Management Scientists. 5(1), 76-86.

[9] Okafor, V. I., Egiyi, M.A. \& Eyisi, A.S. (2017).Relationship between FDI, Capital Market and Nigerian Economy. Journal of Economics and Sustainable Development, 8(14), 254-265.

[10] Okpoto, S. I. (2015). Foreign Private Investment and the Nigeria's Economic Growth (1980-2013). Journal of Policy and Development Studies, 9(3), 2015.

[11] Odo, S. I., Anoke, C.I., Nwachukwu, J. O. \& Promise, E. A. (2016).Impact of Foreign Direct Investment on Stock Market Growth in Nigeria.. Asian Research Journal of Arts and Social Sciences, 1(2), 1-14.

[12] Onyeisi, O. S., Odo, I. S. \& Anoke, C. I. (2016).Foreign Portfolio Investment and Stock Market Growth in Nigeria. Developing Country Studies, 6(11), 64-76.

[13] Eniekezimene, A. F. (2013). The Impact of Foreign Portfolio Investment on Capital Market Growth: evidence from Nigeria. Global Business and Economic Research Journal, 2(8), 13-30.

[14] Ekeocha, P. C., Ekeocha, C. S., Malaolu, V. \& Oduh, M. O. (2012).Modelling the Long Run Determinants of Foreign Portfolio Investment in Nigeria. Journal of Economic and Sustainable Development, 3(8), 194-205.

[15] Baghebo, M. \& Apere, T. O. (2014). Foreign Portfolio Investment and Economic Growth in Nigeria (1986-2011). International Journal of Business and Social Science. 5(1), 108-115.

[16] Abel, E., Ebele, O., \& Ndi O. O. (2009).Stock Market Development and Private Investment Growth in Nigeria. Journal of Sustainable Development in Africa, 2(11), 21-35.

[17] Osmond, N. O. (2016). Foreign Portfolio Investment and Industrial Growth in Nigeria (1986-2013). International Journal of Innovative Finance and Economics Research, 4(3), 31-38.

[18] Muhammad, A. H., Muhammad, A. K., Shamila, S. \& Shujahat, H. H. (2017). The Impact of Stock Market Performance on Foreign Portfolio Investment in China. International Journal of Economics and Financial Issues, $7(2), 460-468$.

[19] Irfan, A. (2014). Impact of Foreign Direct Investment on Volatility of Stock Market (An Evidence from Pakistani Market). IOSR Journal of Business and Management, 16(1), 77-80.

[20] Ali, R., Nasir, I., Zeshan, A., Mohammad, A., \& Tanvir, A. (2012). The Role of FDI on Stock Market Development: The Case of Pakistan. Journal of Economics and Behavioral Studies, 4 (1), 26-33.

[21] Sameh, A. S. (2017). The Effect of Portfolio Investment on Capital Market Indices: Evidence from Amman Stock Exchange. International Review of Management and Business Research, 6(4), 1469-1477. 